Hansen, E., Reeser, P., and Sutton, W., 2018. Phytophthora chlamydospora.

Forest Phytophthoras 8(1). doi: 10.5399/osu/fp.8.1.4566

\title{
Phytophthora chlamydospora
}

\section{Overview}

Phytophthora chlamydospora Brasier and Hansen is found in streams and wet soil worldwide and is a pathogen of some riparian tree species as well as horticulturally valuable fruit and nut trees and nursery stock. It is self-sterile, and produces persistent non-papillate sporangia, usually on unbranched sporangiophores. Chlamydospores are formed most regularly at warmer temperatures. First isolated in 1971 from waterlogged roots of an ornamental Prunus in Gloucestershire, UK, it was tentatively assigned to P. gonapodyides Petersen (Buisman). Similar isolates from Britain and North America were collected and subsequently compared using DNA-based approaches. The UK Prunus isolate and some isolates from nurseries in Oregon and Washington, USA produced large thin-walled chlamydospores in culture and were considered to represent a separate taxon from the nonchlamydospore-forming P. gonapodyides (Brasier et al. 1993). The chlamydospore-forming group was informally designated Phytophthora taxon Pgchlamydo. P. chlamydospora sp. nov., was formally named in 2015 (Hansen et al. 2015).

Etymology: "Chlamydospora" refers to the distinguishing chlamydospores formed especially at higher temperatures. The earlier informal name of "taxon Pgchlamydo" recalls its similarity in culture and habitat to $P$. gonapodyides.

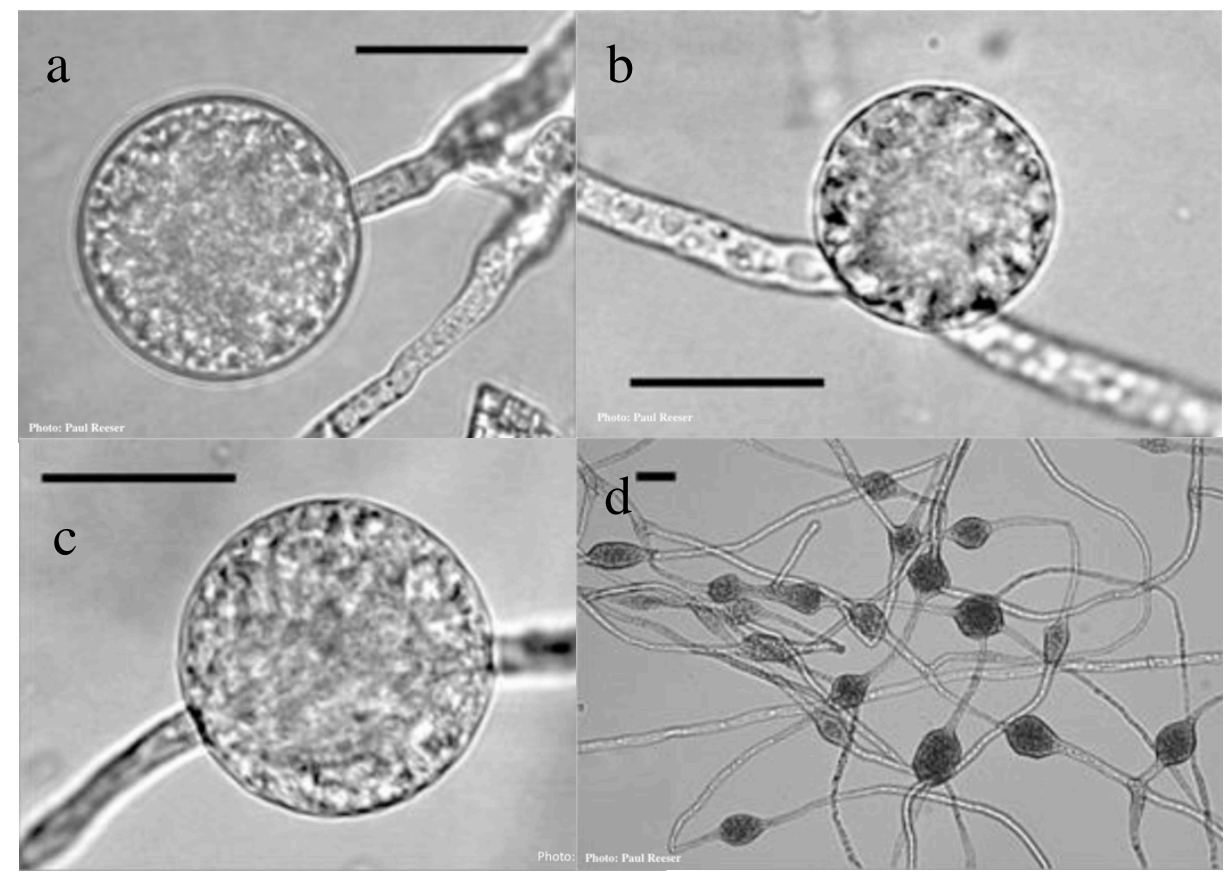

Figure 1. P. chlamydospora chlamydospores in agar (a, b, c) and hyphal swellings in water (d). Bar is $20 \mu \mathrm{m}$. Photos: Paul Reeser

\section{Morphology}

Chlamydospores formed in agar media may be scarce at $22^{\circ} \mathrm{C}$ but are usually abundant at $28^{\circ} \mathrm{C}$. Chlamydospores are mostly intercalary but lateral, terminal and sessile chlamydospores are also observed (Figures $1 \mathrm{a}, \mathrm{b}, \mathrm{c}$ ). Clumps of large globose to subglobose hyphal swellings in branched chains are usually formed in water (Figure $1 \mathrm{~d}$ ). 
Sporangia are formed in water on simple, unbranched (occasionally sympodial) sporangiophores. They are obpyriform or ovoid, often somewhat elongated, non-papillate, persistent (non-caducous), with internal proliferation; average $56 \mu \mathrm{m}$ by $36 \mu \mathrm{m}$, length: breadth ratios from 1.5 to 1.7 (Figure $2 \mathrm{a}-\mathrm{d}$ ). Gametangia have not been observed in single isolate culture i.e. P. chlamydospora appears to be selfsterile. Some isolates exhibit a relic of heterothallism, remaining self-sterile but acting as a 'silent' A1 compatibility type, inducing gametangial formation in A2 isolates of other Phytophthora species when paired directly with them or via a polycarbonate membrane (Brasier et al 1993; 2003).

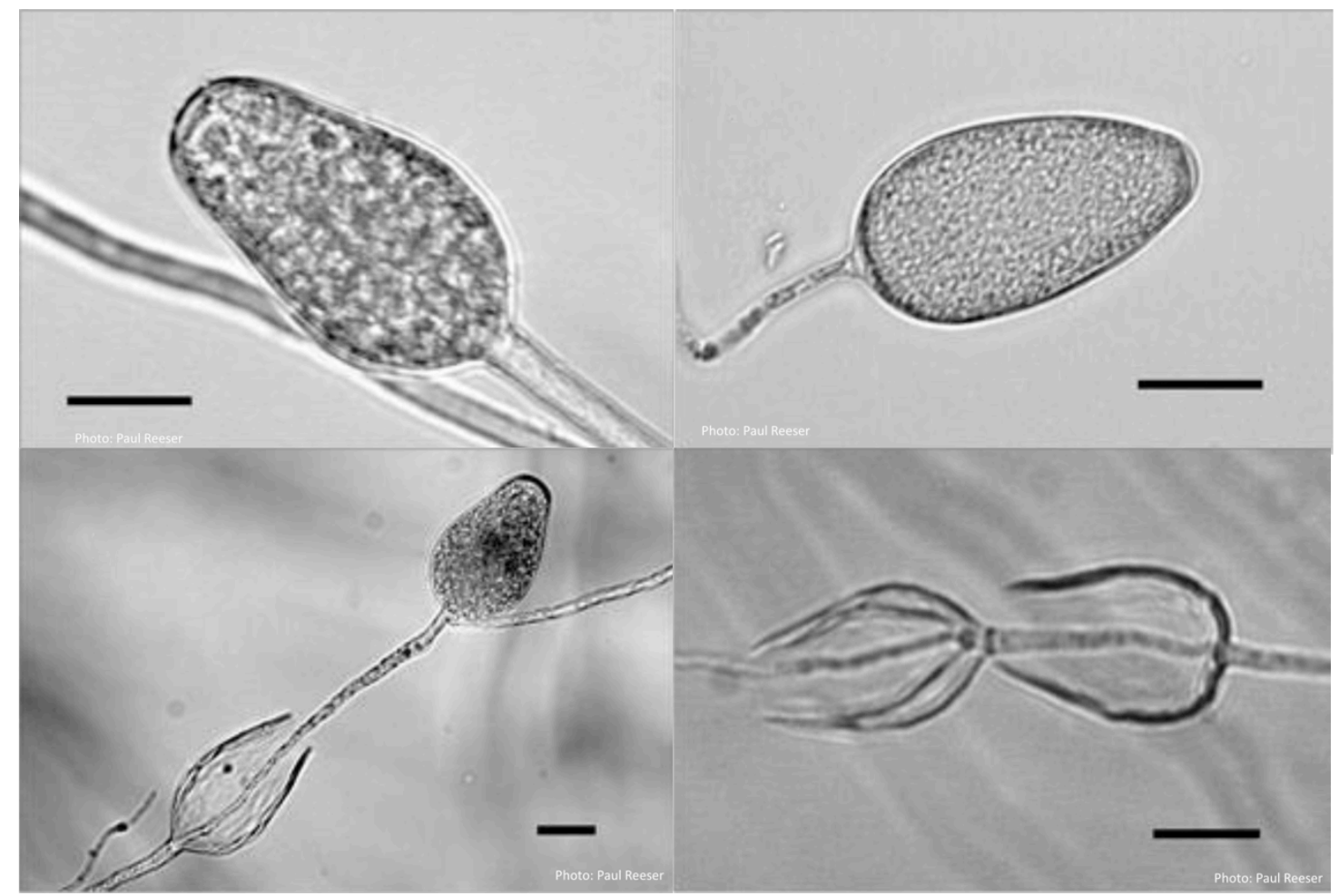

Figure 2. P. chlamydospora sporangia in water, showing subsporangial elongation (lower left) and internal proliferation (lower left and right). Bar is $20 \mu \mathrm{m}$. Photos: Paul Reeser

\section{Growth in culture}

Temperature optimum in vitro mostly ranges from $25-28^{\circ} \mathrm{C}$. Maximum

temperature for growth is $36^{\circ}$ or $37^{\circ} \mathrm{C}$. Growth rate on carrot agar at $25^{\circ} \mathrm{C}$ ranges from 3.2 to $4.1 \mathrm{~mm} / \mathrm{d}$ (Brasier et al. 2003). Colonies on carrot agar are petaloid, very similar to $P$. gonapodyides (Brasier et al. 1993, 2003) (Figure 3).

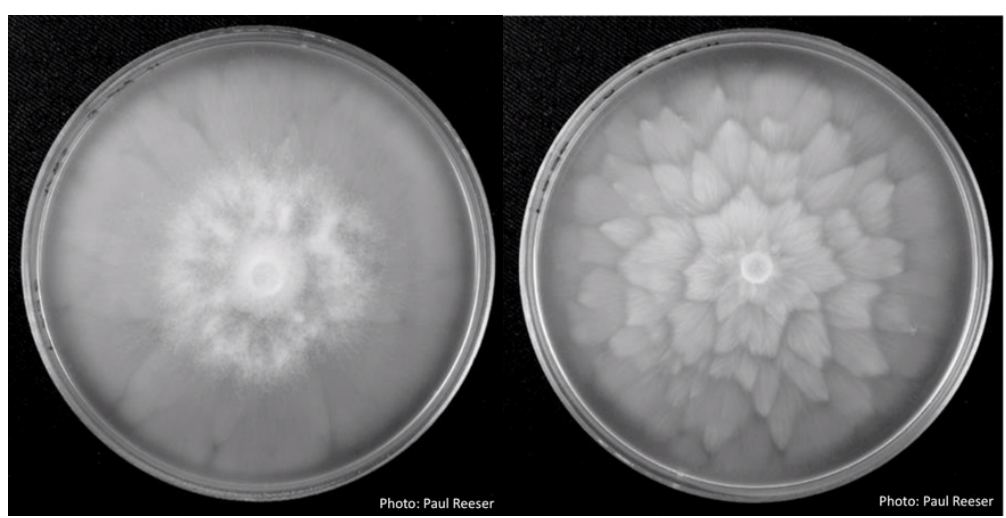

Figure 3. P. chlamydospora isolate P236 on V8 agar (left) and carrot agar (right). Photos: Paul Reeser 


\section{Distinguishing characteristics for identification}

Phytophthora chlamydospora is rather nondescript in culture. It long has been confused with $P$. gonapodyides. Because chlamydospores may not form at lower temperatures this distinguishing feature is not always available. Sporangia usually form rapidly (within 24 hours) in water but are not easily distinguished from those of other non-papillate species. Phytophthora chlamydospora can be misidentified as $P$. lateralis because of its combination of large, sometimes laterally-attached chlamydospores and non-papillate sporangia, but it tolerates much higher growth temperatures. Phytophthora chlamydospora is itself sterile, although it may induce gametangia in A2 isolates of heterothallic species. Without carefully controlled mating tests to determine which isolate is producing gametangia, it often has been assumed to be heterothallic and consequentially misidentified as $P$. drechsleri or P. cryptogea because of its colony morphology and non-papillate sporangia. Clumps of large globose to subglobose hyphal swellings often are observed in water and can be a useful identifying feature. These clumps are sometimes large enough to be visible to the naked eye. Isolates examined from China, Europe, North America and Argentina have been indistinguishable morphologically.

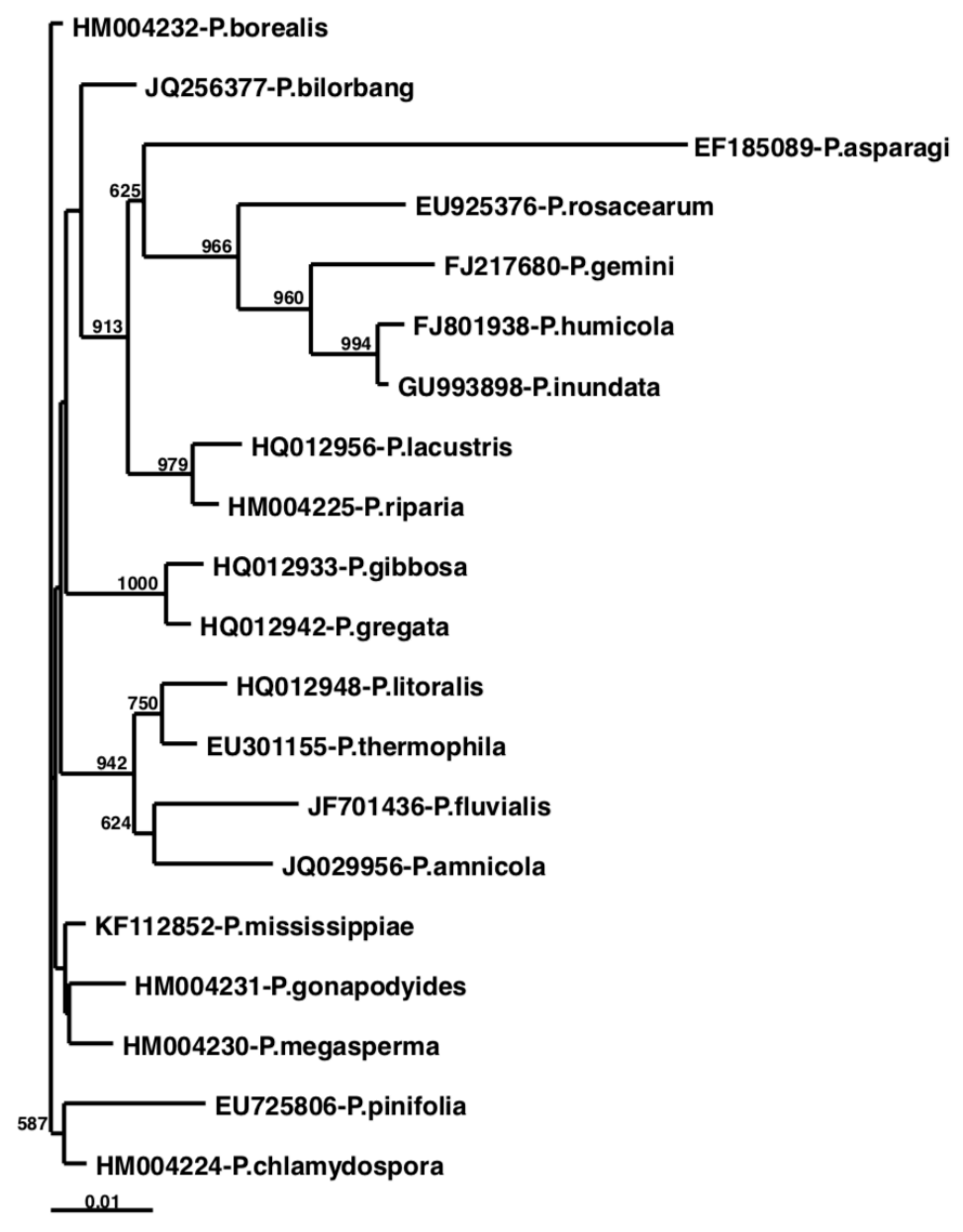

Figure 4. ITS phylogeny of P. chlamydospora in Phytophthora ITS Clade 6 aligned with ClustalX 2.1. The Neighbor Joining tree was generated by Clustal $X$ and displayed with TreeView (Win32). Numbers on nodes represent bootstrap support values $>500$. 


\section{Genetics}

Isolates of Phytophthora chlamydospora form a monophyletic clade within Phytophthora ITS Clade 6 (Figure 4) although with considerable variability expressed as “double peaks," perhaps representing past hybridizations with other clade 6 species. Hybrid isolates are common in some situations. Nagel et al. (2013) have produced molecular and phenotypic evidence for local emergence of hybrid swarms between P. chlamydospora and P. amnicola, or between $P$. chlamydospora and P. thermophila in Australia and South Africa.

Several multilocus genotypes of $P$. chlamydospora have been identified. Isolates with sequences identical to the type isolate, which lacks double peaks in both ITS and $\beta$-tubulin gene regions, are most numerous and are present in both Europe and western North America. The second most frequently encountered multilocus genotype is also found in both Europe and North America. The third genotype was found in five isolates from Argentina. Despite this variation, P. chlamydospora can be distinguished from all other known Phytophthora species by the similarity of its DNA sequences of the ITS, COX spacer, and $\beta$-tubulin gene regions. Phytophthora pinifolia and $P$. borealis are sister species to $P$. chlamydospora. The three species are readily distinguished by growth rate, optimum and maximum temperature, and colony morphology, as well as chlamydospore formation. In addition, $P$. pinifolia exhibits a tendency to cauducity in culture, not observed in P. chlamydospora.

\section{Disease History}

P. chlamydospora is found in streams and wet soil worldwide (Table 1). It is occasionally recovered from cankers on trees and roots in forest situations (Reeser et al. 2008, Navarro et al. 2014, Sims et al. 2014). . It has been associated with root rot of Port-Orford cedar (Chamaecyparis lawsoniana) in German nurseries, where it was initially misidentified as $P$. lateralis (Hansen et al. 1999), and with root rot and stem cankers of Abies species in nurseries and Christmas tree plantations, where it was originally misidentified as P. drechsleri (Brasier et al. 1993). On horticultural hosts, $P$. chlamydospora causes root and crown rot of walnut, almond, and cherry trees (Dervis et al. 2016, Turkolnez et al. 2016, Kurbetli et al. 2017) and foliar lesions and shoot dieback on several ornamental species in nurseries (Jung and Blaschke 2004, Schwingle and Blanchette, 2008, Yakabe et al. 2009, Blomquist et al. 2012, Prospero et al. 2013, Ginetti et al. 2014).

\section{Impacts in the forest}

Apart from its riparian habitat $P$. chlamydospora has been associated with what may be largely opportunistic root infections of Abies and Pseudotsuga in Christmas tree plantations, root rot of ornamental Prunus and Chamaecyparis; and, in one instance, with stem cankers on tanoak ( $N$. densiflorus) in a natural forest (Table 1). Artificial inoculations of several plant species have confirmed that $P$. chlamydospora can be pathogenic on stems and roots (Navarro et al. 2014, Reeser et al. 2008). However, true status of P. chlamydospora as a pathogen in forests has yet to be established. Where it is locally abundant in streams there is usually no visible evidence of disease in adjacent vegetation. In contrast, $P$. chlamydospora appears to be a pathogen of horticulturally valuable species in managed systems where it can cause both root and foliar disease on a range of woody hosts. 


\begin{tabular}{|c|c|c|c|c|c|}
\hline Source & Host Latin name & $\begin{array}{l}\text { Host } \\
\text { common } \\
\text { name }\end{array}$ & Symptoms & Country & Reference \\
\hline Streams & - & - & - & Argentina & $\begin{array}{l}\text { Greslebin et al. } \\
2005\end{array}$ \\
\hline Streams & - & - & - & Chile & Jung et al. 2018 \\
\hline Streams & - & - & - & China & $\begin{array}{l}\text { Huai Wenxia et } \\
\text { al. } 2013\end{array}$ \\
\hline Streams & - & - & - & South Africa & Oh et al. 2013 \\
\hline Streams & - & - & - & Taiwan & Jung et al. 2017 \\
\hline Streams & - & - & - & USA & $\begin{array}{l}\text { Brazee et al. } \\
\text { 2016; Reeser et } \\
\text { al. } 2011\end{array}$ \\
\hline Water & - & - & - & France & $\begin{array}{l}\text { Hansen \& } \\
\text { Delatour } 1999\end{array}$ \\
\hline Soil & - & - & - & Australia & $\begin{array}{l}\text { Burgess et al. } \\
2009 \text {; Jung et al. } \\
2012\end{array}$ \\
\hline Soil & - & - & - & South Africa & Oh et al. 2013 \\
\hline Soil & - & - & - & Germany & $\begin{array}{l}\text { Jung \& Blashke } \\
2004\end{array}$ \\
\hline Forest & $\begin{array}{l}\text { Notholithocarpus } \\
\text { densiflorus }\end{array}$ & tanoak & bole canker & USA & $\begin{array}{l}\text { Reeser et al. } \\
2008\end{array}$ \\
\hline $\begin{array}{l}\text { Nursery, } \\
\text { Christmas tree } \\
\text { plantation }\end{array}$ & Abies procera & Noble fir & $\begin{array}{l}\text { root rot, stem } \\
\text { canker }\end{array}$ & USA & $\begin{array}{l}\text { Brasier et al. } \\
1993\end{array}$ \\
\hline $\begin{array}{l}\text { Nursery, } \\
\text { Christmas tree } \\
\text { plantation }\end{array}$ & Pseudotsuga menziesii & Douglas-fir & root rot & Canada & $\begin{array}{l}\text { Hamm \& } \\
\text { Hansen } 1987\end{array}$ \\
\hline Orchards & $\begin{array}{l}\text { Juglans regia } \\
\text { Prunus cerasis } \\
\text { Prunus dulcis }\end{array}$ & $\begin{array}{l}\text { walnut } \\
\text { almond } \\
\text { sour cherry }\end{array}$ & $\begin{array}{l}\text { root and crown } \\
\text { rot }\end{array}$ & Turkey & $\begin{array}{l}\text { Dervis et al. } \\
\text { 2016; } \\
\text { Turkolmez et al. } \\
\text { 2016; Kurbetli et } \\
\text { al. } 2017\end{array}$ \\
\hline Roadside & Prunus & $\begin{array}{l}\text { ornamental } \\
\text { cherry }\end{array}$ & root rot & UK & $\begin{array}{l}\text { Brasier et al. } \\
\text { 1993; } 2003\end{array}$ \\
\hline Nursery & $\begin{array}{l}\text { Chamaecyparis } \\
\text { lawsoniana }\end{array}$ & $\begin{array}{l}\text { Port-Orford } \\
\text { cedar }\end{array}$ & seedling root rot & Germany & $\begin{array}{l}\text { Hansen et al. } \\
1999\end{array}$ \\
\hline Nursery & $\begin{array}{l}\text { Camellia, } \\
\text { Rhododendron, } \\
\text { Viburnum and } 9 \\
\text { others }\end{array}$ & $\begin{array}{l}\text { various } \\
\text { woody } \\
\text { perennials }\end{array}$ & $\begin{array}{l}\text { leaf lesions, } \\
\text { shoot dieback }\end{array}$ & USA & $\begin{array}{l}\text { Blomquist et al. } \\
\text { 2012; Yakabe et } \\
\text { al. } 2009\end{array}$ \\
\hline Nursery & $\begin{array}{l}\text { Rhododendron } \\
\text { Taxus }\end{array}$ & $\begin{array}{l}\text { rhododendron; } \\
\text { yew }\end{array}$ & $\begin{array}{l}\text { leaf lesions; } \\
\text { dieback }\end{array}$ & USA & $\begin{array}{l}\text { Schwingle \& } \\
\text { Blanchette } 2008\end{array}$ \\
\hline Nursery & Viburnum tinus & laurustinus & $\begin{array}{l}\text { shoot blight, } \\
\text { root and collar } \\
\text { rot }\end{array}$ & Italy & $\begin{array}{l}\text { Ginetti et al. } \\
2014\end{array}$ \\
\hline Nursery & $\begin{array}{l}\text { Rhododendron } \\
\text { Viburnum }\end{array}$ & $\begin{array}{l}\text { rhododendron } \\
\text { viburnum }\end{array}$ & $\begin{array}{l}\text { leaf lesions, } \\
\text { dieback }\end{array}$ & Switzerland & $\begin{array}{l}\text { Prospero et al. } \\
2013\end{array}$ \\
\hline Nursery & Rhododendron & rhododendron & leaf lesions & Spain & $\begin{array}{l}\text { Moralejo et al. } \\
2009\end{array}$ \\
\hline
\end{tabular}




\section{References}

Blomquist, C., , L. E. Yakabe, M.C. Soriano, and M.A. Negrete. 2012. First report of leaf spot caused by Phytophthora taxon Pgchlamydo on evergreen nursery stock in California. Plant Dis. 96:1691. https://doi.org/10.1094/PDIS-02-12-0221-PDN

Brasier, C. M., P. B Hamm and E. M. Hansen. 1993. Cultural characters, protein patterns and unusual mating behavior of Phytophthora gonapodyides isolates from Britain and North America. Mycol. Res. 97:1287-1298.

http://dx.doi.org/10.1016/S0953-7562(09)80160-3

Brasier, C. M., D. E. L. Cooke, J. M. Duncan and E. M. Hansen. 2003. Multiple new phenotypic taxa from trees and riparian ecosystems in Phytophthora gonapodyides-P. megasperma ITS Clade 6 tending to be high temperature tolerant and inbreeding or sterile. Mycol. Res. 107:277-290. https://doi.org/10.1017/S095375620300738X

Brazee, N.J., R.L. Wick, and J.P. Hulvey. 2016. Phytophthora species recovered from the Connecticut River Valley in Massachusetts, USA. Mycologia 108: 6-19. https://doi.org/10.3852/15-038

Burgess, T. I., J. L. Webster, J. A. Ciampini, D. White, G. E. St. J. Hardy and M. J. C. Stukely. 2009. Re-evaluation of Phytophthora species isolated during 30 years of vegetation health surveys in Western Australia using molecular techniques. Plant Dis. 93:215-223. http://dx.doi.org/10.1094/PDIS-93-3-0215

Cooke, D. E. L., A. Drenth, J. M. Duncan, G. Wagels and C. M. Brasier. 2000. A molecular phylogeny of Phytophthora and related oomycetes. Fungal Genet. Biol. 30:17-32. http://dx.doi.org/10.1006/fgbi.2000.1202

Dervis, S., S. Turkolmez, O. Ciftci, and C.Ulubas Serce, 2016. First report of Phytophthora chlamydospora causing root rot on walnut (Juglans regia) trees in Turkey. Plant Dis. 100(11): 2336-2337

http://apsjournals.apsnet.org/doi/10.1094/PDIS-03-16-0306-PDN

Ginetti, B., S. Carmignani, A. Ragazzi, and S. Moricca. 2014. Phytophthora taxon Pgchlamydo is a cause of shoot blight and root and collar rot of Viburnum tinus in Italy. Plant Dis. 98(10): 1432.

http://apsjournals.apsnet.org/doi/10.1094/PDIS-03-14-0282-PDN

Greslebin, A., E. M. Hansen, L. M. Winton and M. Rachenberg. 2005. Phytophthora species from declining Austrocedrus chilensis forests in Patagonia, Argentina. Mycologia 97:218-228.

https:/www.tandfonline.com/doi/abs/10.1080/15572536.2006.11832855?journalCode=umyc20

Hamm, P. B. and E. M. Hansen. 1987. Identification of Phytophthora spp. known to attack conifers in the Pacific Northwest. Northwest Sci. 61:103-109.

Hansen, E. M. and C. Delatour. 1999. Phytophthora species in oak forests of north-east France. Ann. For. Sci. 56:539-547. http://dx.doi.org/10.1051/forest:19990702

Hansen, E. M., P. Reeser, W. Sutton, and C. M. Brasier. 2015. Redesignation of Phytophthora taxon Pgchlamydo as Phytophthora chlamydospora sp. nov. North American Fungi 10(2): 1-14.

https://www.pnwfungi.org/index.php/pnwfungi/article/view/1414

Hansen, E. M., J-C. Streito and C. Delatour. 1999 First confirmation of Phytophthora lateralis in Europe. Plant Dis. 83:587. http://dx.doi.org/10.1094/PDIS.1999.83.6.587B

Huai, W-X., G. Tian, E. M. Hansen, W-X. Zhao, E. M. Goheen, N. J. Grunwald and C. Cheng. 2013. Identifcation of Phytophthora species baited and isolated from forest soil and streams in northwestern Yunnan province, China. Forest Pathol. 43:87-103. http://dx.doi.org/10.1111/efp.12015

Jung, T. and M. Blaschke. 2004. Phytophthora root and collar rot of alders in Bavaria: distribution, modes of spread and possible management strategies. Plant Pathol. 53:197-208. http://dx.doi.org/10.1111/i.0032-0862.2004.00957.x

Jung, T., M. J. Stukely, G. E. Hardy, D. White, T. Paap, W. A. Dunstan and T. I. Burgess. 2011. Multiple new Phytophthora species from ITS Clade 6 associated with natural ecosystems in Australia: evolutionary and ecological implications. Persoonia 26:13-39. http://dx.doi.org/10.3767/003158511X557577 
Jung, T., Chang, T.T., Bakonyi, J., Seress, D., Perez-Sierra, A., Yang, X., Hong, C., Scanu, B., Fu, C.H., Hsueh, K.L., Maia, C., Abad-Campos, P., Leon, M. , and Horta Jung, M. 2017. Diversity of Phytophthora species in natural ecosystems of Taiwan and association with disease symptoms. Plant Pathol. 66(2): 194-211. https://doi.org/10.1111/ppa.12564

Jung, T., A. Duran, E.S. von Stowasser, L. Schena, S. Mosca, S. Fajardo, M. Gonzalez, A.D. Navarro Ortega, J. Bakonyi, D. Seress, M. Tomsovsky, A. Cravador, C. Maia, and M.H. Jung. 2018. Diversity of Phytophthora species in Valdivian rainforests and associated with severe dieback symptoms. Forest Pathol. 48(5): e12443. https://doi.org/10.1111/efp.12443

Kurbetli, İ., M. Aydoğdu, and G. J. Sülü, 2017. Phytophthora chlamydospora and P. megasperma associated with root and crown rot of sour cherry in Turkey. Plant Dis. Prot. (2017) 124: 403. https://doi.org/10.1007/s41348-017-0075-y.

Mills, S. D., H. Forster and M. D. Coffey. 1991. Taxonomic structure of Phytophthora cryptogea and P. drechsleri based on isozyme and mitochondrial DNA analyses. Mycol. Res. 95:31-48. http://dx.doi.org/10.1016/S0953-7562(09)81359-2

Moralejo, E., A. M. Perez-Sierra, L. A. Alvarez, L. Belbahri, F. Lefort and E. Descals. 2009. Multiple alien Phytophthora taxa discovered on diseased ornamental plants in Spain. Plant Pathol. 58:100-110.

http://dx.doi.org/10.1111/j.1365-3059.2008.01930.x

Nagel, J. H., M. Gryzenhout, B. Slippers, M. J. Wingfield, G. E. Hardy, M. J. Stukely and T. I. Burgess. 2013. Characterization of Phytophthora hybrids from ITS clade 6 associated with riparian ecosystems in South Africa and Australia. Fungal Biol. 117:329-47. http://dx.doi.org/10.1016/j.funbio.2013.03.004.

Navarro, S., L. Sims and E. Hansen. 2015. Pathogenicity to alder of Phytophthora species from riparian ecosystems in western Oregon. Forest Pathol. Article first published online: 16 FEB 2015 http://dx.doi.org/10.1111/efp.12175

Oh, E., M. Gryzenhout, B. D. Wingfield, M. J. Wingfield and T. I. Burgess. 2013. Surveys of soil and water reveal a goldmine of Phytophthora diversity in South African natural ecosystems. IMA Fungus 4: 123-131.

http://dx.doi.org/10.5598/imafungus.2013.04.01.12

Prospero, S., A. Vercauteren, K. Heungens, L. Belbahri, and D. Rigling, 2013. Phytophthora diversity and the population structure of Phytophthora ramorum in Swiss ornamental nurseries. Plant Pathol. 62: 1063-1071.

https://doi.org/10.1111/ppa.12027

Reeser, P. W., W. L. Sutton and E. M. Hansen. 2008. Phytophthora species causing tanoak stem cankers in southwestern Oregon. Plant Dis. 92:1252. http://dx.doi.org/10.1094/PDIS-92-8-1252B

Reeser, P. W., W. Sutton, E. M. Hansen, P. Remigi and G. C. Adams. 2011. Phytophthora species in forest streams in Oregon and Alaska. Mycologia 103:22-35.

http://dx.doi.org/10.3852/10-013

Schwingle, B. W., J. A. Smith and R. A. Blanchette. 2007. Phytophthora species associated with diseased woody ornamentals in Minnesota nurseries. Plant Dis. 91: 97-102. http://dx.doi.org/10.1094/PD-91-0097

Sims, L. 2014. Phytophthora species and riparian alder tree damage in western Oregon. PhD thesis. Oregon State University. http://hdl.handle.net/1957/46441

Türkölmez, Ş, S. Derviş, O. Çiftçi, , and Ç. Ulubaş Serçe. 2016. First report of Phytophthora chlamydospora causing root and crown rot on almond (Prunus dulcis) trees in Turkey. Plant Dis. 100(8): 1796. https://doi.org/10.1094/PDIS-02-16-0155-PDN

White, T. J., T. D. Bruns, S. Lee and J. Taylor. 1990. Amplification and direct sequencing of fungal ribosomal RNA genes for phylogenetics. In: PCR Protocols - A Guide to Methods and Applications. (Innis MA, Gelfand DH, Sninsky JJ, White TJ, eds). New York: Academic Press. http://dx.doi.org/10.1016/B978-0-12-372180-8.50042-1

Yakabe, L. E., C. L. Blomquist, S. L. Thomas and J. D. MacDonald. 2009. Identification and frequency of Phytophthora species associated with foliar diseases in California ornamental nurseries. Plant Dis. 93:883-890.

https://apsjournals.apsnet.org/doi/pdf/10.1094/PDIS-93-9-0883 